\title{
微小共振器におけるカーコムの数值シミュレーション法
}

\author{
藤井 瞬，鈴木 良，堀 敦裕，久保田 啓寛，田邊 孝純 \\ 慶應義塾大学 理工学部電子工学科 ( \%223-8522 神奈川県横浜市港北区日吉 3-14-1)
}

\section{Numerical Simulation Method of Kerr Comb in a Microcavity}

\author{
Shun FUJII, Ryo SUZUKI, Atsuhiro HORI, Akihiro KUBOTA, and Takasumi TANABE \\ Faculty of Science and Technology, Keio University, 3-14-1 Hiyoshi, Kohoku-ku, Yokomaha-shi, Kanagawa 223-8522
}

(Received September 18, 2017)

\begin{abstract}
In this study, numerical modeling and simulations of Kerr frequency comb and Kerr soliton in microcavities were performed with nonlinear coupled mode equation (NCME) and Lugiato-Lefever equation (LLE). We compared two methods and performed simulations of mode-locked Kerr comb in microcavities with anomalous and normal dispersions.
\end{abstract}

Key Words: Microcavity, Kerr frequency comb, Four-wave mixing, Optical soliton

\section{1.はじめに}

高 $Q$ 值かつ低モード体積 $V$ 有する微小光共振器を用 いると, 三次非線形光学効果を低パワーの連続 (Continuous Wave: CW )レーザー光入力で発生することができ $ろ^{1,2)}$. 近年, 縮退四光波混合 (Degenerate Four-Wave Mixing: DFWM) と非縮退四光波混合 (Non-Degenerate FourWave Mixing: NDFWM) が連鎖的に発生することにより 周波数軸上に等間隔な光スペクトルを形成する光カーコ ムの研究が盛んに行われている ${ }^{3,4)}$. 光カーコムはマイ クロコムともよばれ，従来の光周波数コム光源と比較し て, 非常にコンパクトで低消費エネルギー, 高い繰り返 し周波数 (Free Spectral Range: FSR)を持つという特長が ある. 特にシリカ $\left(\mathrm{SiO}_{2}\right)^{5,6)}$ やシリコンナイトライド $\left(\mathrm{Si}_{3} \mathrm{~N}_{4}\right)$ 共振器 7 はCMOS互換プロセスで作製できること から，シリコンチップ集積が可能である。 さらに分散設 計も容易であることから, 非常に多くの研究が報告され るようになってきた。 その一方でフッ化マグネシウム $\left(\mathrm{MgF}_{2}\right)$ に代表されるフッ化物材料は, チップ集積は難 しいが，前者と比較して非常に高い $Q$ 值を達成できると いう特徵をもつ ${ }^{8)}$. このような様々な共振器材料とリン グやディスク，ロッドといった共振器構造との組み合わ せで数多くのプラットフォームが報告されるようにな り，それぞれの特性を生かしたカーコムの研究が行なわ れている。

2014年にはモードロック（縦モード間の位相が揃った） した光カーコムの発生が実証された ${ }^{9)}$ 。このとき報告さ れたパルス幅(FWHM) は200 fsであった。このような共 振器内を周回する光パルスはカーソリトン (Dissipative Kerr Soliton: DKS) とよばれ，モードロックしていない光 カーコムであるMIコム (Modulation Instability Comb) 状態
と明確に区別されている。またここでいう散逸性(Dissipative) とは分散性と非線形性，利得と損失という2つの 平衡が成り立っていることを意味しており，ファイバ レーザーのソリトンモード同期手法やそのソリトンとし て知られる散逸性ソリトンとは異なることに注意された い. Fig. 1 にCW励起光からFWMを介して発生する光 カーコムとカーソリトンの概要図を示した。モードロッ クした光カーコムは低位相ノイズの光源となりうるた め, RF信号発生器 ${ }^{10)}$ やコヒーレント光通信 ${ }^{11)}$, デュアル コム分光 ${ }^{22}$ といった様々な応用が実験室レベルで達成さ れつつある

また，実験による光カーコム，カーソリトンの観測に加
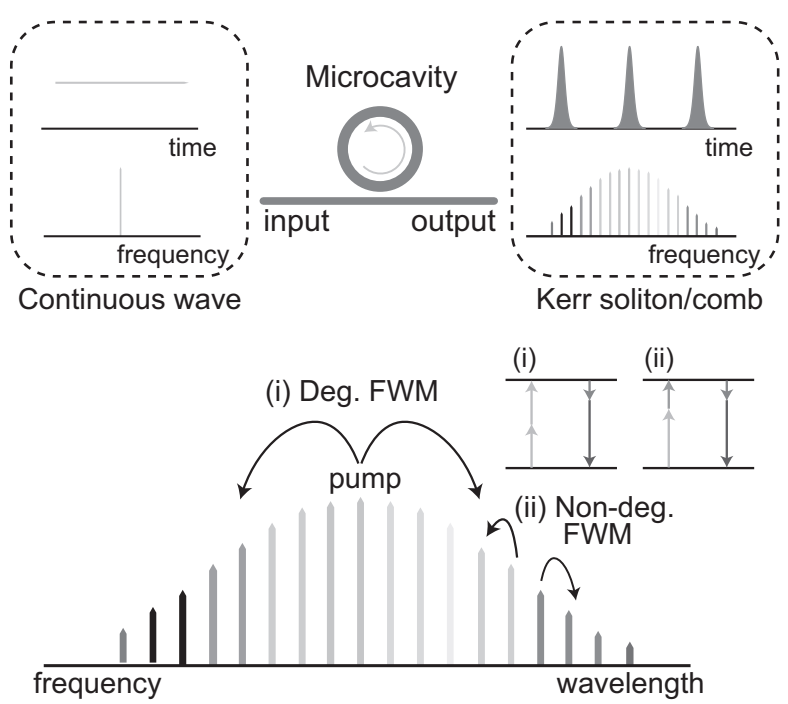

Fig. 1 Schematic illustration of Kerr soliton and comb formation via degenerate and non-degenerate fourwave mixing by continuous wave pump. 
えて数值シミュレーションによる研究も進展してきた. 正 確な数值シミュレーションは実験に必要なパラメータを 検討し, 実験にフィードバックすることを可能にするだけ でなく，新たな実験手法や理論の提案に大きな役割を果 たすことになる。実際に，光カーコムの初期の研究にお いては, 位相同期状態(カーソリトン)をどのようにして得 るのかの実験的手法が明らかではなく，励起光の波長や パワーを掃引することで位相同期が実現できることが理 論計算の助けも借りながら明らかにされてきた。

本論文では光カーコムの数值シミュレーションに用い られる2つの異なる手法について検討する。一つが非線形 結合モード方程式(Nonlinear Coupled Mode Equation: NCME)であり，他方が非線形シュレディンガー方程式 (Nonlinear Schrödinger Equation: NLSE)を基本とするLugiato-Lefever Equation: LLEである。 この2つの手法は独立に 発展してきたので, 近年まで本質的に同等であることは 明確に示されてこなかった，本論文で初めてこの2つの手 法による計算結果を直接比較検討し, 同等性を確認する とともに，それぞれの特徵について明らかにする。また， 異常分散におけるカーソリトン発生に関する詳細な解析 と, 正常分散で光カーコムを発生するための結合共振器 モデルを利用した数值シミュレーションについても示す.

\section{2. カーコムのモデリング手法}

\subsection{Nonlinear Coupled Mode Equation (NCME)}

光カーコムのシミュレーション手法の一つがNCMEを 用いる方法である ${ }^{8,9,13)}$. NCMEは各コムモードの複素電 界振幅が緩慢変化包絡線 (Slowly-Varying Envelope: SVE) として近似できることを前提としており，任意の縦モー ド数に対して非線形モード方程式を立式し, それらを結 合方程式として連立することで，光スペクトル発展と， スペクトルのフーリエ変換に対応する時間波形を逐次計 算する手法である。非線形結合モード方程式は $\left|a_{\mu}\right|^{2}$ が各 モードの光子数で規格化されるコムモード $a_{\mu}$ の微分方程 式として次のように立式される.

$$
\begin{aligned}
\frac{d a_{\mu}}{d t}=\left[\frac{\gamma}{2}+i\left(\omega_{\mu}-\omega_{0}\right.\right. & \left.\left.+\Delta-\mu D_{1}\right)\right] a_{\mu} \\
& +i g \sum_{j, k} a_{j} a_{k} a_{j+k+\mu}^{*}+f \delta_{\mu}
\end{aligned}
$$

ここで $t$ は時間, $\gamma=\omega_{0} / Q=\omega_{0} / Q_{\mathrm{int}}+\omega_{0} / Q_{\mathrm{ext}}$ は共振器 $Q$ 值 に対応する共振器ロス, $\omega_{\mu}$ は各モードの共振周波数, $\Delta=$ $\omega_{0}-\omega_{\mathrm{p}}$ は励起される共振周波数と入力周波数の差である デチューニングを表している。 このとき添字 $\mu$ は励起さ れる共振周波数 $(\mu=0)$ を基準としたときのモード番号を 表しており, 共振器の共振モードは次の式で与えられる。

$$
\omega_{\mu}=\omega_{0}+\mu D_{1}+\frac{1}{2 !} \mu^{2} D_{2}+\frac{1}{3 !} \mu^{3} D_{3}+\cdots
$$

$D_{1}$ は共振器FSR, $D_{2}, D_{3}$ はそれぞれ二次分散, 三次分 散を表しており, 群速度分散パラメータである $\beta_{2}\left(\mathrm{ps}^{2} / \mathrm{km}\right)$ とは $D_{2}=-\left(c / n_{0}\right) D_{1}^{2} \beta_{2}$ という関係がある. このように共振
器の分散は $D_{1}$ 間隔の等間隔な周波数グリッドからの共振 周波数の差(ずれ)であり, $D_{2}>0$ は異常分散, $D_{2}<0$ は正 常分散を表す。右辺第3項は四光波混合や自己位相変調 といった光カー効果を表しており, $g=\left(\hbar \omega_{0}^{2} n_{2} c\right) / n_{0}^{2} V_{\text {eff }}$ は 非線形係数である。ここでちは換算プランク定数, $n_{0}$ は 屈折率, $n_{2}\left(\mathrm{~m}^{2} / \mathrm{W}\right)$ は非線形屈折率, $c$ は真空中の光速, $V_{\text {eff }}$ は実効モード体積を表しており, 共振器長 $L$ 実効 モード面積 $A_{\mathrm{eff}}$ と $V_{\mathrm{eff}}=A_{\mathrm{eff}} L$ の関係が成り立つ。このとき 添字 $j, k も \mu$ と同様にモード番号を表しており, これら の総和計算は自動的に位相整合条件を満たす関係のみを 考慮している．最後の第四項は外部入力を表しており， $f=\left[\left(\gamma_{\mathrm{ext}} P_{\mathrm{in}}\right) / \hbar \omega_{0}\right]^{1 / 2}$ は導波路との結合レート $\gamma_{\mathrm{ext}}=\omega_{0} / Q_{\mathrm{ext}}$ と入力パワー $P_{\mathrm{in}}(\mathrm{W})$ から決定される係数である. $\delta_{\mu}$ は クロネッカーのデルタを表し, 励起モード $\omega_{0}$ にのみ外部 入力が作用する. 非線形結合モード方程式は初期条件と して非常に弱い白色ノイズを与え，4次のルンゲクッタ 法により解くことができる。またFFTによる高速化手法 が提案されており ${ }^{14)}$ ，この手法を用いることで計算コス トが低減できる。

\subsection{Lugiato-Lefever Equation (LLE)}

カーコムシミュレーションのもう一つの手法がLLEを 利用する方法である ${ }^{15,16)}$. LLEはNLSEを共振器モデルに 拡張したモデルであり, デチューニング項と外部入力項 が存在する点がNLSEと異なる，数学的には，LLEにお

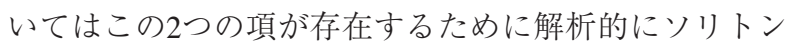
解を求めることが不可能となる点がNLSEとは異なる.

NCMEは各コムモードの時間発展がそれぞれの方程式で 表されるのに対してLLEは共振器一周の境界条件の下 に，場全体の変化を計算する。境界条件を $\phi=[-\pi, \pi]$ と おいたとき, ここで計算される共振器の内部場はフーリ 工変換の関係から $A(\phi, t)=\Sigma_{\mu} a_{\mu}(t) \exp (i \mu \phi)$ と表され, LLEは以下の式で与えられる。

$$
\frac{\partial A(\phi, t)}{\partial t}=-\left(\frac{\gamma}{2}+i \Delta\right) A+i \frac{D_{2}}{2} \frac{\partial^{2} A}{\partial \phi^{2}}+i g|A|^{2} A+f
$$

ここで $\phi$ は共振器円周上の位置に対応する方位角, $t$ は時 間を表している。右辺の各項は順に共振器ロス, デ チューニング, 分散, 光カー効果, 外部入力を表す. NCMEとの大きな違いは周期境界条件の存在である。こ れによりスプリットステップフーリエ法を用いて計算す ることができ，高速な解析が可能となる。

\section{3 モデリングの特徵と実験結果との比較}

異なる二つのモデリングを導入したが，これらは相補 的なアプローチであり，同じ条件であれば当然同等の結 果を導く。しかし，NCMEでは任意の縦モード数を設定 できるほか, 熱光学効果や異なる横モード間のモード結 合を容易に導入することができる。一方でLLEの場合は 誘導ラマン散乱やブリルアン散乱, 自己急峻化といった 非線形効果を加えることに適しており ${ }^{17)}$ ，シミュレー ションの用途に応じて利用することが可能である. ここ ではNCMEとLLEの同等性を比較するため, 誘導ラマン 
散乱のような他の非線形効果を含めないものとした。し かし実際には, 誘導ラマン散乱はソリトン自己周波数シ フトを引き起こすだけでなく、ソリトンの発生条件にも 影響を与えることが分かっている ${ }^{18)}$.

Fig. 2 にNCMEとLLEを用いた光カーコムのシミュレーショ ン結果と実験結果を示す。計算パラメー夕は $Q=1 \times 10^{8}$, $Q_{\mathrm{ext}}=2 \times 10^{8}$, 中心周波数 $\omega_{0}=2 \pi \times 193 \mathrm{THz}, \mathrm{FSR}=$ $145 \mathrm{GHz}$ ，2次分散 $D_{2}=2 \pi \times 550 \mathrm{kHz}\left(\beta_{2}=-20 \mathrm{ps}^{2} / \mathrm{km}\right)$, 非 線形倸数 $g=0.0086 \mathrm{rad} / \mathrm{s}$, 入力パワー $P_{\mathrm{in}}=70 \mathrm{~mW}$ とし

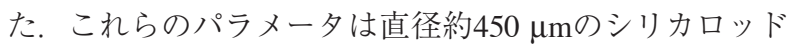
共振器を仮定している. また, 微小光共振器は一般的に 複数の横モードを保持しているが, ここでは1次のTE モードを仮定して扮り，このとき有効モード面積は $A_{\text {eff }}=$ $40 \mu \mathrm{m}^{2}$ とした. FSR と分散(材料分散+導波路分散) 扮よ び有効モード面積は有限要素法 (Finite Element Method: FEM）を用いて計算した，簡単のためここに示す計算で は3次以降の高次分散は無視しているが, 一般的に高次 分散は分散波やクラスターコム ${ }^{19)}$ といった現象を引き起 こすことが知られており, 光カーコムの広帯域化に用い られる場合がある。 Fig2(a)，(b)はNCMEによる結果, Fig. 2 (c)，（d）はLLEによる結果であり，挿入図はそれぞ れの時間波形を示している。 どちらもシングルソリトン が達成されて扔り，この結果から2つのモデリングが全く 同等の結果を示すことが確かめられた，Fig. 2(e) はシリ カロッド共振器 (Fig. 2(f)) を用いて実験的に観測された 光スペクトルである。このとき $1545 \mathrm{~nm}$ 付近で非常に強い 光が観測されたが，これは透過したポンプ光によるもの である。実験で得られた光スペクトルは計算結果とよく 似ているが，この状態はカーソリトンではなくモード ロックしていないMIコムであると考えられる。実験にお いて安定なカーソリトンを得るためにはソリトンが発生 した時点において熱平衡状態を達成することが重要であ り，そのために掃引開始波長，掃引停止波長，レーザー
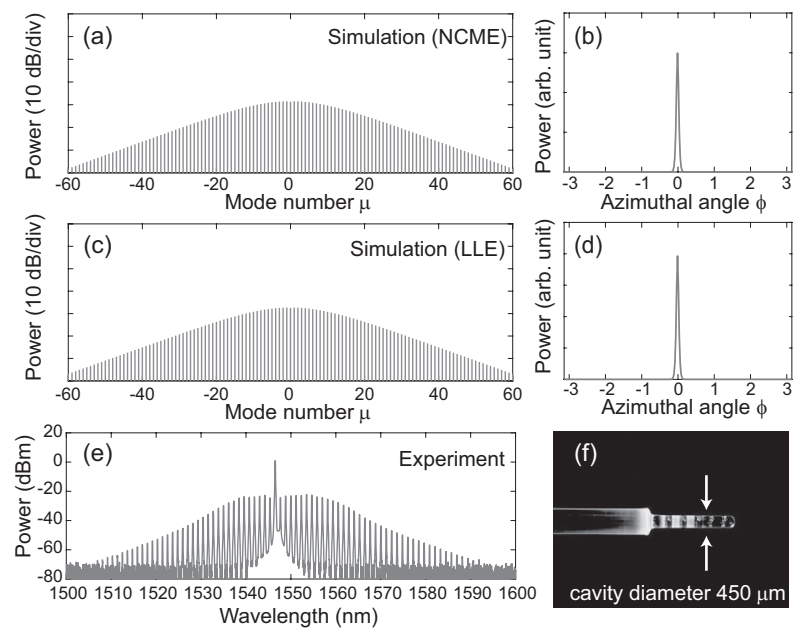

Fig. 2 (a), (b) Numerical simulation results with nonlinear coupled mode equation (NCME). (c), (d) Numerical simulation results with Lugiato-Lefever equation (LLE). (e) Experimental result in a silica rod microcavity. (f) Silica rod whispering gallery mode (WGM) microcavity with a diameter of $\sim 450 \mu \mathrm{m}$.
掃引速度といったパラメータを最適な值に調整する必要 がある。

最後に, NCMEとLLEのそれぞれの特徵をTable 1にま とめる。

3. LLEによるカーソリトンのシミュレーション

3.1 レーザー波長掃引によるカーソリトン発生

光カーコムにはチューリングパターン (Turing pattern), カオス(Chaos), カーソリトン(Dissipative Kerr soliton)の3つの状態があることが知られており，これら は共振器内部パワーの変化を観測することで明らかとな

Table 1 Comparison of NCME and LLE.

\begin{tabular}{|c|c|c|}
\hline & $\begin{array}{l}\text { Master } \\
\text { equation }\end{array}$ & Characteristics \\
\hline NCME & $\begin{array}{l}\text { Coupled mode } \\
\text { equation }\end{array}$ & $\begin{array}{l}\text { Setting of an arbitrary number of } \\
\text { modes, Mode coupling term }\end{array}$ \\
\hline LLE & $\begin{array}{l}\text { Nonlinear } \\
\text { Schrödinger } \\
\text { equation }\end{array}$ & $\begin{array}{l}\text { Nonlinear effects (stimulated } \\
\text { Raman scattering/stimulated } \\
\text { Brillouin scattering/self-steeping; } \\
\text { analytical description of soliton } \\
\text { solution) }\end{array}$ \\
\hline
\end{tabular}
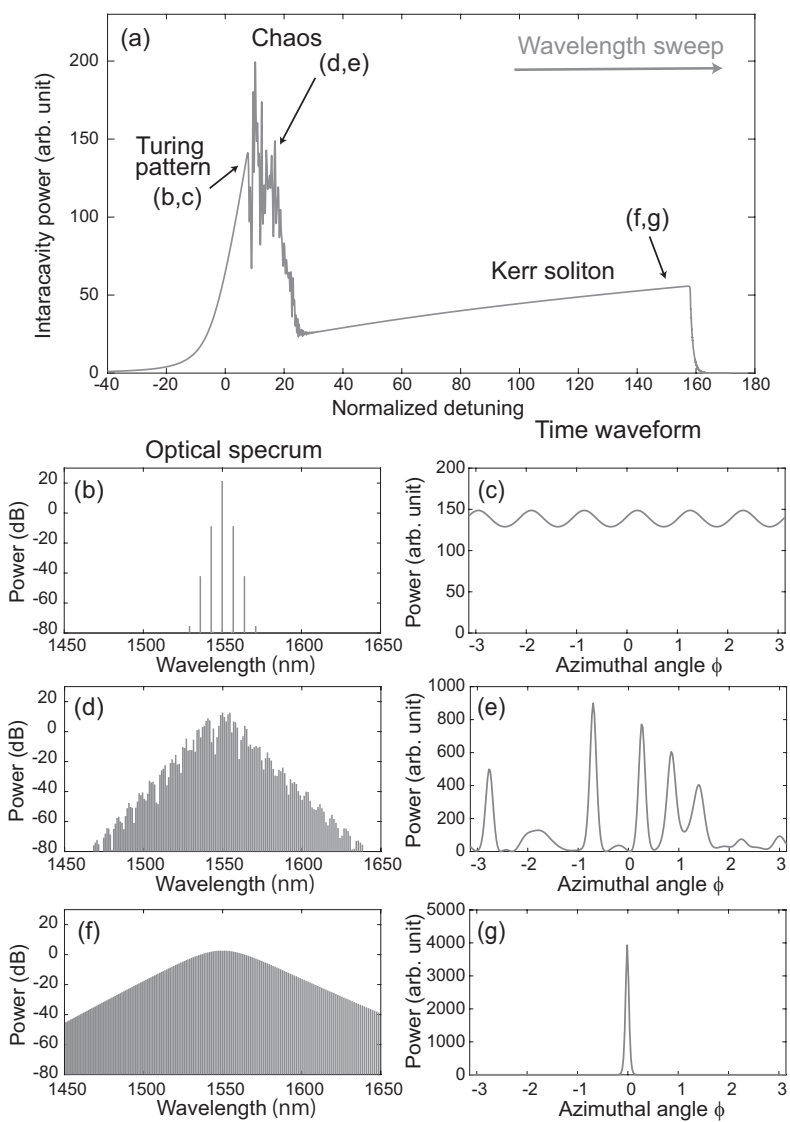

Fig. 3 (a) Intracavity power during a wavelength scan toward red wavelength. (b), (c) Turing pattern. Spectrum and time waveform are stable but not a soliton. (d), (e) Chaotic state. Spectrum and time waveform are unstable. (f), (g) Kerr soliton state. 
る. Fig. 3(a)に励起波長を長波長側へ連続的に変化させ たときの共振器内部パワーの変化を示した。内部パワー の増加とともにまず発生するのは, チューリングパター ンコムである(Fig. 3(b, c))，チューリングパターンでは 周期的な強度分布が得られるが，この状態はまだカーソ リトンではない，そのあと内部パワーが乱雑に変化し， 光スペクトル，時間波形ともに不安定になる。この状態 がカオスであり, カーソリトンへ移行する前の段階であ るといえる(Fig. 3 (d, e ) ). カーソリトンになると内部パ ワーは急激に減少して安定し, sech 関数で表されるソ リトン波形となる $(F i g .3(\mathrm{f}, \mathrm{g}))$. このような特徴的な変 化は異常分散の共振器に共通してみられることが知られ ている ${ }^{9)}$.

\section{2 カーソリトンのランダム性}

カーソリトンを得る手法としては前述したレーザー波 長掃引による方法が最も一般的である. しかし，この方 法では発生するソリトン数にはランダム性があり, 同じ パラメータを用いた場合でも確定的に単一ソリトンを得 ることができない。これは同じデチューニング量に対し て, パルス数の異なる安定なソリトン解が複数存在する ことに起因する.

Fig. 4 に同じパラメータを用いて4回計算を繰り返した ときの共振器内部パワーの推移を示す.

それぞれ1，2，3ソリトンとソリトン化しない場合があ り，これらがランダムに発生した。このようなランダム 性はシステムがカオス状態を経由することが原因で発生 するとされており，最近ではソリトン数の制御に関する 研究が報告されている20).

また，それらの解を満たすようにソリトン数が減少し ながら内部パワーがランダムに変化する場合が存在し, このとき発生する内部パワーの階段状の変化はソリトン ステップとよばれる ${ }^{9,211}$.

\section{NCMEによるダークソリトンシミュレーション}

4.1 モード結合を利用した正常分散カーコム CW励起光からDFWMによって発生するサイドバンド

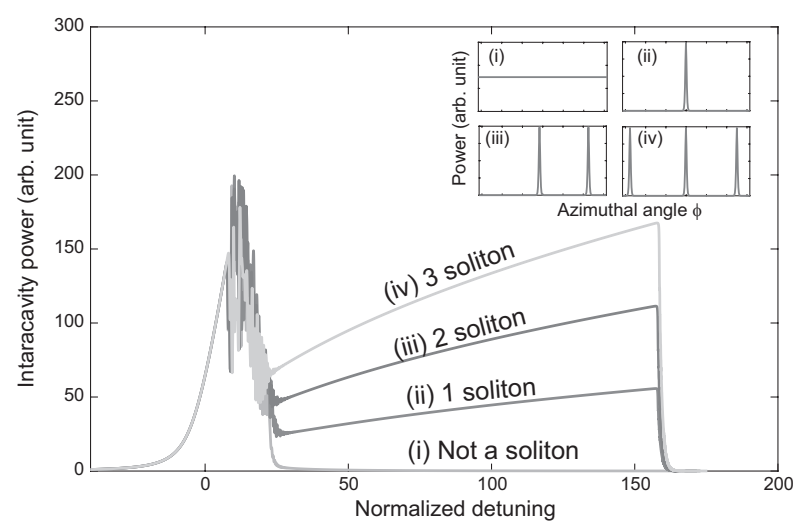

Fig. 4 Intracavity power when the calculation with the same parameters is repeated four times. Insets show time waveforms corresponding to (i-iv).
光の発生には異常分散における変調不安定性が必要とさ れる，そのため正常分散では光カーコムの発生条件を容 易に満たすことができず，異常分散におけるカーソリト ンと比較して，正常分散領域におけるカーソリトンであ るダークソリトンの発生は困難であるとされてきた。し かし最近になって異なる共振波長の相互作用であるモー ド結合を利用することで正常分散領域中に局所的な異常 分散点を作り出し，そこを起点として光カーコムが発生 させる手法が実験的に実証された ${ }^{22,23)}$.

モード結合を利用した正常分散コムの発生メカニズム をFig. 5 に示す。異なる共振モードの強結合状態ではそ れぞれの共振波長は擬交差(アンチクロッシング)し，実 効的に共振波長がシフトする。特定の共振波長のシフト は正常分散を局所的に異常分散へ変化させることと等価 であるため, そのモードを起点として位相整合条件が満 たされポンプ光からDFWMが発生する。 サイドバンド 光の発生後は変調不安定性を必要としないNDFWMが連 鎖的に発生することで正常分散領域においても光カーコ ムは広帯域化する。ここでは2つの共振モード間におけ るモード結合を考慮したNCMEを新たに構築し，正常分 散カーコムのシミュレーションを行った結果を示す.

\section{2 モード結合項を含むNCME}

モード結合は異なる共振モードの相互作用であるた め，それぞれのモードに関するNCMEを以下のように立 式する。

$$
\begin{array}{r}
\frac{d a_{\mu}}{d t}=-\left[\frac{\gamma_{A}}{2}+i\left(\omega_{\mu A}-\omega_{0}+\Delta-\mu D_{1 A}\right)\right] a_{\mu} \\
+i g_{A} \sum_{j, k} a_{j} a_{k} a_{j+k-\mu}^{*}+i \frac{\kappa_{\mu}}{2} b_{\mu}+f \delta_{\mu} \\
\frac{d a_{\mu}}{d t}=-\left[\frac{\gamma_{B}}{2}+i\left(\omega_{\mu B}-\omega_{0}+\Delta-\mu D_{1 B}\right)\right] b_{\mu} \\
+i g_{B} \sum_{j, k} b_{j} b_{k} b_{j+k-\mu}^{*}+i \frac{\kappa_{\mu}}{2} a_{\mu}
\end{array}
$$
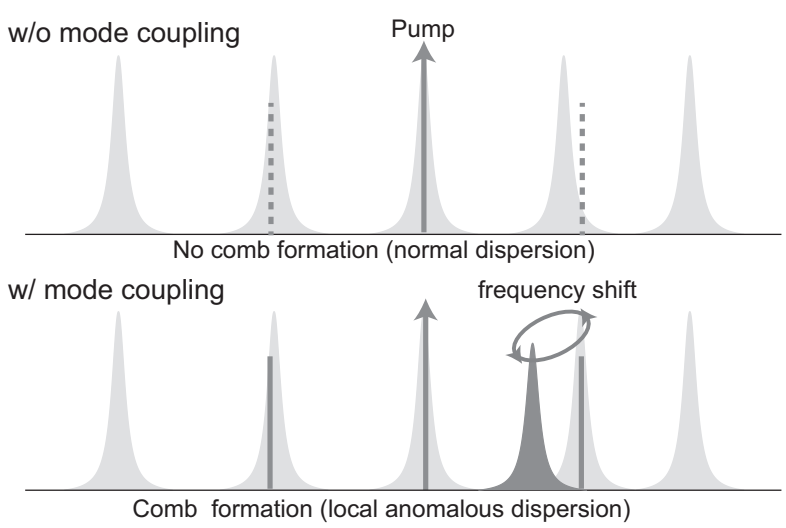

Fig. 5 Schematics of comb formation via mode coupling in normal dispersion system. Mode coupling induces the frequency shift, which makes the local anomalous dispersion in that mode. As a result, phase-matching is satisfied, and initial comb sidebands generated. 
$a_{\mu}$ が外部入力のある主モード (Main)， $b_{\mu}$ がモード結合を 引き起こすための補助モード(Aux.), 右辺第四項のКが 結合レートを表している。 それぞれのパラメータは独立 であり，2つの共振器モードを並列に計算するため計算 コストは倍になる。

\section{3 シミュレーション結果}

計算パラメータはシリコンナイトライド共振器を仮定 した ${ }^{22)}$. 主モードの各值は $Q=8.6 \times 10^{5}, Q_{\mathrm{ext}}=2.7 \times 10^{6}$, $\omega_{A 0}=2 \pi \times 195 \mathrm{THz}, \mathrm{FSR}=231.4 \mathrm{GHz}, D_{2 A}=2 \pi \times-9.1 \mathrm{MHz}$, $g_{A}=4.20 \mathrm{rad} / \mathrm{s}$ とし, 補助モードは $Q=8.6 \times 10^{5}, \omega_{B 0}=\omega_{A 0}+$ $2 \pi \times 465 \mathrm{MHz}, \mathrm{FSR}=231.16 \mathrm{GHz}, D_{2 B}=2 \pi \times-9.1 \mathrm{MHz}$, $g_{B}=4.20 \mathrm{rad} / \mathrm{s}$, 入力パワー $P_{\mathrm{in}}=400 \mathrm{~mW}$, 結合レート $\kappa=$ $2 \pi \times 500 \mathrm{MHz}$ とした。このときの実効モード面積はどち らも $A_{\text {eff }}=1.10 \mu \mathrm{m}^{2}$ とした

実験的にはモード結合を補助するモードに異なる共振 器を用いる方法と, 同一共振器内の異なる横モードを利 用する方法があるが，結合レートと各モードのパラメー 夕を設定すればそのどちらもシミュレーションが可能で ある. Fig. 6 にシミュレーション結果を示した。モード 結合を利用した正常分散コムの発生では異常分散の光 カーコムとはいくつか異なる特徴がみられる。デチュー ニングを変化させていくと(Fig. 6(a))，あるデチューニ ングに達したときに光カーコムが発生するが，このとき カオスを経由することなくダークソリトン状態に達する
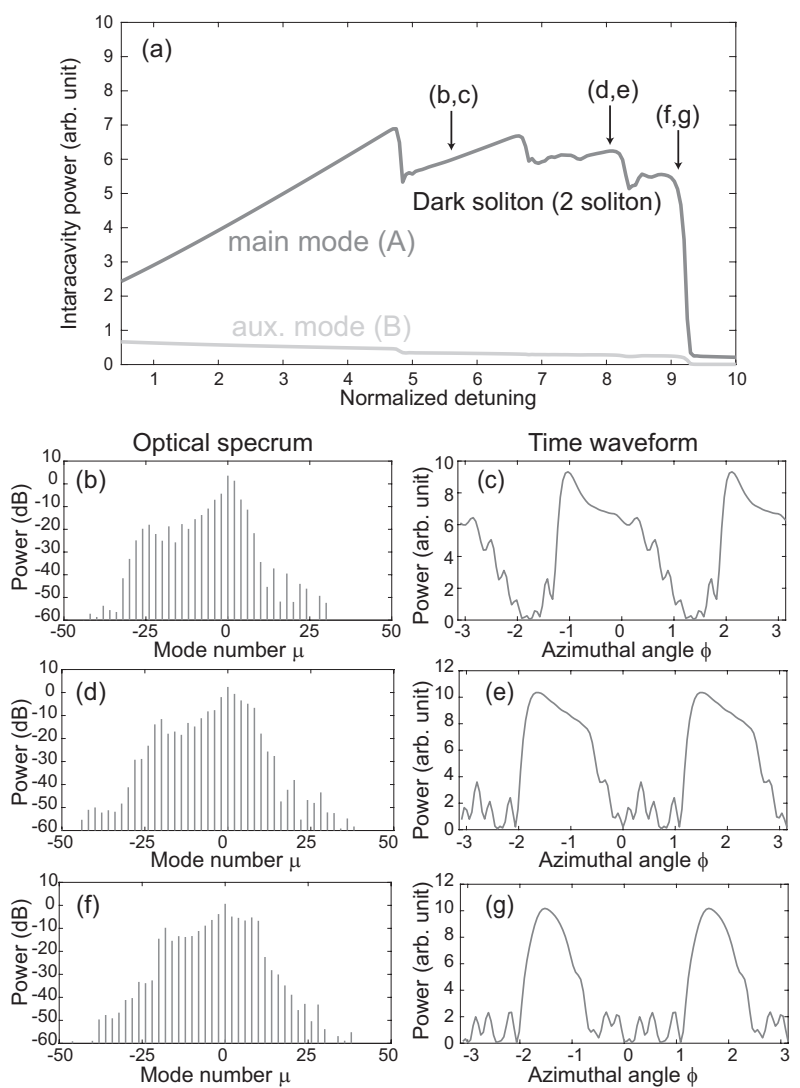

Fig. 6 (a) Intracavity power during a wavelength scan. 2-FSR comb and dark soliton are generated without chaotic state. (b, d, f) Optical spectra. (c, e, g) Time waveforms.
(Fig. 6(b, c)). さらに共振器内部パワーがステップ状に 変化したとき，異常分散で発生するようなソリトン数の 変化が起こらず，ソリトン数は常に維持されながらスぺ クトルと時間波形が徐々に変化していく(Fig. 6(d, e, f, g)）。また，繰り返し計算を行っても内部パワーが同じ 経路をたどることから，異常分散においてみられるよう なランダム性が正常分散ではみられないことが分かっ た。このような特徴は先行研究における実験 22,23$) て ゙$ 観測 された特徵とよく一致しており，本モデルの正確性およ び，確かに正常分散を有する共振器では結合したモード の擬交差を起点としてダークソリトンが生成することが 確認できた。

\section{5. 結 論}

本論文では微小光共振器を用いて発生される光カーコ ムおよびカーソリトンの数值シミュレーション手法であ るLugiato-Lefever方程式(LLE) と非線形結合モード方程 式(NCME)の，2つのモデルによるシミュレーション結 果を比較し，モデルの同等性を確認した。実際にこの2 つの手法を用いて直接計算結果を比較し，さらに実験結 果と照らし合わせたのは本論文が初めての試みである.

また，異常分散領域におけるカーソリトン発生の手法と 特徵を議論したあとに，モード結合を利用した正常分散 領域における光カーコムとダークソリトンの正確な数值 モデリングを新たに提案した。ここに示す結果は光カー コム，カーソリトンの応用に向けて数值シミュレーショ ンの妥当性を裏付けるとともに，共振器構造の設計や実 験結果を理論的にサポートするものとなることが期待さ れる。

\section{謝 辞}

本研究の遂行にあたり理論面でのご助言をいただいた 宮路 智行氏 (明治大学特任講師) 及び, 加藤 拓巳氏と 岡部 悠介氏に深く感謝申し上げます。本研究の一部は 科研費(JPISH05429)の支援を受けて行われました。

\section{参考文献}

1) K. J. Vahala: Nature 424 (2003) 839

2) T. Tanabe, M. Notomi, E. Kuramochi, A. Shinya, and H. Taniyama: Nat. Photonics 1 (2007) 49.

3) P. Del'Haye, A. Schliesser, O. Arcizet, T. Wilken, R. Holzwarth, and T. J. Kippenberg: Nature 450 (2007) 1214.

4) P. Del'Haye, T. Herr, E. Gavartin, M. L. Gorodetsky, R. Holzwarth, and T. J. Kippenberg: Phys. Rev. Lett. 107 (2011) 063801.

5) D. K. Armani, T. J. Kippeneberg, S. M. Spillane, and K. J. Vahala: Nature 421 (2003) 925.

6) H. Lee, T. Chen, J. Li, K. Y. Yang, S. Joen, O. Painter, and K. J. Vahala: Nat. Photonics 6 (2012) 369.

7) D. J. Moss, R. Morandotti, A. L. Gaeta, and M. Lipson: Nat. Photonics 7 (2013) 597.

8) A. A. Savchenkov, A. B. Matsko, D. Strekalov, M. Mohageg, V. S Ilchenko, and L. Maleki: Phys. Rev. Lett. 93 (2004) 243905.

9) T. Herr, V. Brasch, J. Jost, C. Wang, N. Kondratiev, M. L. Gorodetsky, and T. J. Kippenberg: Nat. Photonics 8 (2014) 145.

10) W. Liang, D. Eliyahu, V. S. Ilchenko, A. A. Savchenkov, A. B. 
Matsko, D. Seidel, and L. Maleki: Nat. Commun 6 (2015) 7957.

11) J. Pfeifle, V. Brasch, M. Lauermann, Y. Yu, D. Wegner, T. Herr, K. Hartinger, P. Schindler, J. Li, D. Hillerkuss, et al.: Nat. Photonics 8 (2014) 375.

12) M.-G. Suh, Q.-F. Yang, K. Y. Yang, X. Yi, and K. J. Vahala: Science 354 (2016) 600.

13) Y. K. Chembo and N. Yu: Phys. Rev. A 82 (2010) 033801.

14) T. Hansson, D. Modotto, and S. Wabnitz: Opt. Commun. 312 (2014) 134.

15) L. A. Lugiato and R. Lefever: Phys. Rev. Lett. 58 (1987) 2209.

16) Y. K. Chembo: Phys. Rev. A 87 (2013) 053852.

17) G. Lin, S. Diallo, J. M. Dudley, and Y. K. Chembo: Opt. Express 24 (2016) 14880.
18) C. Milián, A. V. Gorbach, M. Taki, A. V. Yulin, and D.V. Skryabin: Phys. Rev. A 92 (2015) 033851.

19) S. Fujii, T. Kato, R. Suzuki, and T. Tanabe: Opt. Lett. 42 (2017) 2010.

20) H. Guo, M. Karpov, E. Lucas, A. Kordts, M. H. P. Pfeiffer, V. Brasch, G. Lihachev, V. E. Lobanov, M. L. Gorodetsky, and T. J. Kippenberg: Nat. Phys. 13 (2017) 94.

21) T. Kato, A.-C. Jinnai, T. Nagano, T. Kobatake, R. Suzuki, W. Yoshiki, and T. Tanabe: Jpn. J. Appl. Phys. 55 (2016) 072201.

22) X. Xue, Y. Xuan, Y. Liu, P. Wang, S. Chen, J. Wang, D. Leaird, M. Qi, and A. M. Weiner: Nat. Photonics 9 (2015) 594.

23) X. Xue, Y. Xuan, P.-H. Wang, Y. Liu, D. E. Leaird, M. Qi, and A. M. Weiner: Laser Photonics Rev. 9 (2015) L23. 